\title{
Eating habits in university students of health science programs
}

\author{
Susuky Mar-Aldana ${ }^{*}$, Ana R. Rodríguez-Durán², José C. Castañeda-Delfín ${ }^{3}$, Miriam H. Rodríguez-López ${ }^{4}$, \\ Leticia Pesqueira-Leal ${ }^{5}$, Arturo Barraza-Macias ${ }^{6}$, and Jorge A. Cisneros-Martínez ${ }^{1}$ \\ ${ }^{1}$ School of Medicine and Nutrition, Universidad Juarez del Estado de Durango; ${ }^{2}$ School of Social Work, Universidad Juarez del Estado de Durango; \\ ${ }^{3}$ School of Infirmary and Obstetrics, Universidad Juarez del Estado de Durango; ${ }^{4}$ School of Chemical Sciences, Universidad Juarez del Estado \\ de Durango; ${ }^{5}$ School of Psychology and Human Communication Therapy, Universidad Juarez del Estado de Durango; ${ }^{6}$ Research and Postgraduate \\ Department, Universidad Pedagógica de Durango. Durango, Durango, Mexico
}

\begin{abstract}
Objective: The objective of the study was to evaluate eating habits in university students who belong to health science programs. Methods: The study was conducted to 1503 students from the health area of five institutions of the Juarez University of the State of Durango: FAMEN (32.5\%), FAPYTCH (23.4\%), FAEO (16.1\%), FODO (14.2\%), and FCCFYD (13.8\%). Each student was given an instrument to assess their eating habits. Results: There are few statistical differences in the ITEMS of the instrument applied to evaluate eating habits in university students of health science programs, presenting a low consumption of fruits, vegetables, protein-rich foods, and low water consumption. In contrast, there is a high intake of processed and high-calorie food. Conclusions: It is concluded that there is no difference between the variables of the instrument applied in the participating population, noting that students evaluated in both men and women are on a mostly regular scale, and when questioning the population studied about how often they follow a diet, a high percentage responded that sometimes, and a minimum percentage always mentions being within a diet.
\end{abstract}

Key words: Eating habits. College students. Health.

\section{Introduction}

Health and education are valuable assets to the state of well-being and, thus, fundamental columns of Mexico. The National Survey of Health in Schools (2018) highlights the fact that although school performance is linked to different factors, health issues linked to diet and nutrition significantly affect the students' ability to learn'.

Thus, it was important to conduct this research to assess the eating habits of higher education students who belonged to science programs at the "Juarez University of the State of Durango" (UJED by its Spanish acronym), since it is well-known that not all people follow a proper dietary regime, and even the people who attend a consultation with a nutritionist quit or do not follow the suggestions made to them.

Exogenous obesity is linked to sedentarism and bad dietary habits. Today, it is considered a worldwide epidemic and an emerging public health issue. Being overweight or obese leads to greater mortality risk, as well as to the development of different diseases such as diabetes, hypertension, ischemic cardiopathy, and cerebral vascular accidents, which are the main causes of death in our country-4.

Obesity and overweight are defined as the abnormal or excessive accumulation of fat, which can be adverse to health. A simple way of measuring obesity is the body

\section{Correspondence:}

*Susuky Mar-Aldana

E-mail: susuky@ujed.mx
Available online: 01-12-2021

Date of reception: 26-02-2021

Date of acceptance: 30-07-2021 DOI: 10.24875/RMU.21000017
Medicina Universitaria. 2021;23(4):112-120 www.medicinauniversitaria.org

1665-5796/@ 2021 Universidad Autónoma de Nuevo León. Published by Permanyer. This is an open access article under the CC BY-NC-ND license (http://creativecommons.org/licenses/by-nc-nd/4.0/). 
mass index (BMI). This is the weight of a person in kilograms divided by the square of their height in meters. Anybody with a BMI equal to or greater than 30 is considered obese. Moreover, a person with a BMI equal to or greater than 25 is considered overweight. Obesity and overweight are considered risk factors for numerous chronic diseases, including diabetes, cardiovascular diseases, and cancer ${ }^{5}$.

Many patients attend medical consults with the idea that obesity is resolved by following a diet without considering other areas in their lives. Sometimes, this attitude can be strengthened by the professional, who focuses the entire patient's attention on weight loss, leaving aside the need to modify their habits and lifestyle ${ }^{6,7}$.

A balanced diet not only provides the essential nutrients for proper physical development but also proper intellectual development. However, having proper dietary habits are a matter of education rather than money, since people often spend a lot of money on food with low nutritional value, commonly known as "junk food"8.

We are conducting this research in the spirit of contributing to the development of scientific knowledge since, thus far, there is no record of studies with the proposed reference. Therefore, the main objective of this research is to assess the perception of dietary habits in university students who belong to health sciences programs imparted at the "Juarez University of the State of Durango."

\section{Materials and methods}

A quantitative study was conducted for this investigation, gathering and analyzing data to answer research questions, thus proving a hypothesis previously developed, relying on numerical measurements, counts, and frequency in the use of statistics to establish behavioral patterns within a population accurately.

The research was developed in the state of Durango considering a study population of 1503 university students properly enrolled in the maximum house of studies and belonging to the health science programs.

The percentage of students who participated by school is described below:

1. School of Medicine and Nutrition (FAMEN by its Spanish acronym) with a total sample of 488 students (32.5\%)

2. School of Psychology and Human Communication Therapy (FAPYTCH by its Spanish acronym) with 352 students (23.4\%)
3. School of Nursing and Obstetrics (FAEO by its Spanish acronym) with 242 students (16.1\%)

4. School of Odontology (FODO by its Spanish acronym) with 214 students (14.2\%)

5. School of Physical Culture and Sport Sciences (FCCFYD by its Spanish acronym) with 207 students (13.8\%).

The qualitative variables of this investigation include higher education students from the Health Sciences programs at the UJED, and the quantitative variables were their dietary habits.

Dietary habits were evaluated using an instrument designed by the authors of this research. This instrument was called "Instrument to assess the dietary regime in Health Sciences students" (Annex 1), which was utilized as a technique to gather information on different aspects of the subjects in this study, and an analysis of the measurements and impact of the study, therefore determining dietary conditions according to each subject. The instrument was validated using the Cronbach alpha item analysis before the study with a population of 40 volunteer students.

For the application of the questionnaire, we benefited from the support of 15 students in their $5^{\text {th }}$ semester of the Nutrition Bachelor's degree at the FAMEN. For a period of 6 weeks, these students were responsible for commuting and taking the instruments to the different learning institutions included in this research. It is worth noting that they were supervised and accompanied by the researchers responsible for this study for the entire time. The students in charge of the surveys were trained and prepared by the researchers so that they knew the questions in the questionnaire and the correct way to apply them.

The questionnaire included the weight and height of the interviewees to calculate BMI using a calibrated, portable, and an easy-to-transport measuring device (Omron HBF-514C scale and Avanutri 315 portable stadiometer).

After conducting the aforementioned measurements, the obtained results were shared with each of the subjects personally, so they were informed of their status and received a brief explanation of what this measurement meant.

Each participant of the different institutions of the UJED required written consent to be evaluated, and data collection was performed at the institutions where they were enrolled. The subjects were selected through a list provided by the school services department at the UJED. The university included the number of students officially registered from the first to the eighth semester. 
Finally, the answers obtained through this instrument were analyzed using the software SPSS Statistics V.20. The following tests were conducted: Cronbach's alpha reliability tests, index calculation, average, mean, standard deviation, and range.

The study adhered to the guidelines established by the General Health Law guidelines in health-care research, always respecting the dignity of the subjects with a polite and professional treatment and the protection of their human rights.

\section{Results}

The study included 1503 students from five higher learning institutions from the Juarez University of the State of Durango: 488 students from the FAMEN (32.5\%), 352 from the FAPYTCH (23.4\%), 242 from the FAEO (16.1\%), 214 from the FODO (14.2\%), and 207 from the FCCFYD (13.8\%), presenting a Cronbach's alpha reliability of 0.876 .

Table 1 describes the demographic characteristics of the interviewees, considering the number of students from the different learning institutions, the distribution of students from all the different majors, the total of students enrolled by semester, and the male-female ratio of those who participated in the study.

The results were obtained by calculating indexes; we established a hierarchy of ponderations that responded to the values measured concretely in dietary habits and regime.

The mean age of the interviewees was 20.87 years of age with a standard deviation of 2.61, ranging from 17 to 45 years of age, with most of them being around 20 years old $(22.6 \%)$.

Most interviewees, 984 students $(65.5 \%)$, presented a BMI with normal weight; however, some of them were overweight, and others had some degree of obesity (Table 2).

Results from Table 3 correspond to the consideration of students' dietary habits, where $835(55.6 \%)$ responded to be regular compared to $42(2.8 \%)$ students who selected the option of excellent.

When questioned about the perseverance that university students have to follow a dietary regime (Table 4), 505 students (33.6\%) sometimes answered, followed by 448 students $(29.8 \%)$ who answered that they have never followed one and $36(2.4 \%)$ students who said that they were always within a dietary regime.

Following this line, the interviewees were asked about who indicated said dietary regime, 1058 (70.4\%) students responded that they did it by themselves,
Table 1. Demographic characteristics of university students

\begin{tabular}{|c|c|c|}
\hline Faculty & $\mathbf{n}$ & Percentage (\%) \\
\hline FAMEN & 489 & 32.5 \\
\hline FAPYTCH & 352 & 23.4 \\
\hline FAEO & 242 & 16.1 \\
\hline FODO & 213 & 14.2 \\
\hline FCCFYD & 207 & 13.8 \\
\hline Degree & n & Percentage (\%) \\
\hline Medicine & 283 & 18.8 \\
\hline Nutrition & 206 & 13.7 \\
\hline Psychology & 218 & 14.5 \\
\hline Communication Therapy & 134 & 8.9 \\
\hline Nursing & 242 & 16.1 \\
\hline Dentistry & 213 & 14.2 \\
\hline Physical Education & 207 & 13.8 \\
\hline Semester & n & Percentage (\%) \\
\hline First & 256 & 17.0 \\
\hline Second & 280 & 18.6 \\
\hline Third & 284 & 18.9 \\
\hline Fourth & 192 & 12.8 \\
\hline Fifth & 157 & 10.4 \\
\hline Sixth & 131 & 8.7 \\
\hline Seventh & 124 & 8.3 \\
\hline Eighth & 79 & 5.3 \\
\hline Sex & n & Percentage (\%) \\
\hline Male & 528 & 35.1 \\
\hline Female & 975 & 64. \\
\hline Age & n & Percentage (\%) \\
\hline 17.00 & 3 & 0.2 \\
\hline 18.00 & 126 & 8.4 \\
\hline 19.00 & 323 & 21.5 \\
\hline 20.00 & 339 & 22.6 \\
\hline 21.00 & 282 & 18.8 \\
\hline 22.00 & 180 & 12.0 \\
\hline 23.00 & 102 & 6.8 \\
\hline 24.00 & 62 & 4.1 \\
\hline 25.00 & 35 & 2.3 \\
\hline 26.00 & 14 & 0.9 \\
\hline
\end{tabular}


Table 1. (Continued)

\begin{tabular}{|l|l|l|}
\hline Age & $\mathbf{n}$ & Percentage (\%) \\
\hline 27.00 & 9 & 0.6 \\
\hline 28.00 & 6 & 0.4 \\
\hline 29.00 & 5 & 0.3 \\
\hline 30.00 & 2 & 0.1 \\
\hline 32.00 & 1 & 0.1 \\
\hline 33.00 & 3 & 0.2 \\
\hline 34.00 & 1 & 0.1 \\
\hline 35.00 & 1 & 0.1 \\
\hline 37.00 & 3 & 0.2 \\
\hline 40.00 & 1 & 0.1 \\
\hline 41.00 & 3 & 0.2 \\
\hline 43.00 & 1 & 0.1 \\
\hline 45.00 & 1 & 0.1 \\
\hline Total & 1503 & 100.0 \\
\hline Source: own research & & \\
\hline
\end{tabular}

$274(18.2 \%)$ said that it was directed by a nutritionist, $92(6.1 \%)$ students indicated that it was recommended by an acquaintance, and 60 (4\%) answered that a physician had indicated the diet.

The students were questioned whether they followed their dietary indications, 1045 (69.5\%) responded "almost always," 310 (20.6\%) said "sometimes," 71 (4.7\%) students said "always," and $14(0.9 \%)$ students said "never."

Regarding their dietary habits, 48 (3.2\%) students answered that they did not have any, while 510 (33.9\%) responded "only sometimes," 464 (30.9\%) students said "almost always," and 332 (22.1\%) said "always."

In their frequency of dietary habits, 421 (28\%) students in the health area mentioned that they had breakfast at home, and 143 (9.5\%) mentioned that they never had breakfast at home. They were also asked whether they ate lunch at home, and $410(27.3 \%)$ students said "always," and $39(2.6 \%)$ said that they never eat at home. When asked if they prepared their meals, $523(34.8 \%)$ answered "sometimes," and 164 (10.9\%) said "rarely."

Concerning their physical activity, 497 (33.1\%) students answered that they sometimes performed physical activity. On the other hand, 138 (9.2\%) of the students stated that they never performed it.
Table 2. BMI level in university students

\begin{tabular}{|l|c|c|}
\hline Level & $\mathbf{n}$ & Percentage (\%) \\
\hline Low weight & 99 & 6.6 \\
\hline Normal weight & 984 & 65.5 \\
\hline Overweight & 337 & 22.4 \\
\hline Obese grade 1 & 72 & 4.8 \\
\hline Obese grade 2 & 10 & 0.7 \\
\hline Obese grade 3 & 1 & 0.1 \\
\hline Total & 1503 & 100 \\
\hline
\end{tabular}

Source: own research

Table 3. Consideration of eating habits in university students

\begin{tabular}{|l|c|c|}
\hline Habits & $\mathbf{n}$ & Percentage (\%) \\
\hline Bad & 154 & 10.2 \\
\hline Regular & 835 & 55.6 \\
\hline Good & 472 & 31.4 \\
\hline Excellent & 42 & 2.8 \\
\hline Total & 1503 & 100.0 \\
\hline
\end{tabular}

Source: own research

Table 4. The consistency with which university students follow a diet

\begin{tabular}{|l|c|c|}
\hline Diet & $\mathbf{n}$ & Percentage (\%) \\
\hline Never & 448 & 29.8 \\
\hline Almost never & 387 & 25.7 \\
\hline Sometimes & 505 & 33.6 \\
\hline Almost always & 127 & 8.4 \\
\hline Always & 36 & 2.4 \\
\hline Total & 1503 & 100.0 \\
\hline
\end{tabular}

Source: own research

In their daily consumption of three meals a day, we were able to observe that 705 (47\%) students answered that their diet is "very healthy," $485(32.3 \%)$ responded "healthy," 286 (17.2\%) said "not healthy," and 53 (3.5\%) students said "unhealthy."

To determine their daily consumption of protein-rich foods such as meat, chicken, fish, cheese, eggs, and 
Table 5. Correlation between study variables

\begin{tabular}{|l|c|c|c|c|c|}
\hline & $\begin{array}{c}\text { Level of daily } \\
\text { consumption }\end{array}$ & $\begin{array}{c}\text { Level of protein } \\
\text { consumed }\end{array}$ & $\begin{array}{c}\text { Level of fruits and } \\
\text { vegetables consumed }\end{array}$ & $\begin{array}{c}\text { Level of sausages } \\
\text { consumed }\end{array}$ & Family diet level \\
\hline $\begin{array}{l}\text { Faculty to which the } \\
\text { student belongs }\end{array}$ & 0.040 & 0.035 & -0.041 & $0.087^{* *}$ & $0.052^{*}$ \\
\hline Career completed & 0.121 & 0.178 & 0.110 & 0.001 & 0.042 \\
\hline Sex & 0.049 & 0.011 & -0.045 & $0.057^{*}$ & 0.036 \\
\hline Relationship status & 0.060 & 0.658 & 0.080 & 0.028 & $-0.104^{* *}$ \\
\hline Number of family & -0.023 & $-0.117^{* *}$ & 0.025 & $-0.110^{* *}$ & 0.000 \\
\hline members & 0.383 & 0.000 & 0.328 & 0.000 & 0.023 \\
\hline Eating habits & $0.051^{*}$ & 0.038 & 0.002 & 0.038 & 0.372 \\
\hline & 0.047 & 0.139 & 0.948 & 0.144 & -0.017 \\
\hline & 0.025 & -0.028 & -0.024 & 0.004 & 0.030 \\
\hline
\end{tabular}

Source: Own elaboration using Pearson's correlation (bilateral)

grains, $612(40.7 \%)$ of the subjects stated that they did not healthily consume them, contrary to $56(3.7 \%)$ who answered that they healthily consumed them.

From the studied population, $648(43.1 \%)$ responded that their daily consumption of fruits and vegetables, including natural juices, was "not healthy," 478 (31.8\%) said "not very healthy," $216(14.4 \%)$ said "regularly healthy," and $161(10.7 \%)$ students answered that they had a healthy food intake.

Regarding processed food, which includes sausages, boxed, enveloped, or bottled beverages, carbonated drinks, packed snacks, pastries, pancakes, and consumption of sweets and chocolate, results show that $32(2.1 \%)$ students consume these products in a "healthy" manner, 526 (35\%) did so in a "not so healthy" manner, $122(8.1 \%)$ answered that they did so in a "regularly" healthy manner, and 824 (54.8\%) answered in an "unhealthy" manner.

From the analyzed results on the level of a family dietary regime, results show that $821(54.6 \%)$ were "not very healthy," followed by $434(28.9 \%)$ who were "unhealthy," 231 (15.4\%) who were "regularly healthy," and only $17(1.1 \%)$ as "healthy."

Using the Pearson's correlation (bilateral) statistical study to search for a connection between the faculty and the students belonged to and the level of consumption being $p>0.05$, we found that there were no connections, and neither were there any connections with the level of protein consumed, nor fruit consumption. However, there was a relationship between the consumption of sausages and the level of family dietary regime, although the levels were very low (0.087 and 0.052) (Table 5).

Moreover, there were no links between the major the students were enrolled for and their daily consumption, level of protein consumption, fruit and vegetable consumption, or the family dietary regime. However, there was a connection with the consumption of sausages, although a very low one (0.057).

Furthermore, there was no evidence of a relationship between daily consumption and fruit and vegetable consumption. However, there was a relationship with protein consumption, sausage consumption, and family dietary regime, although with an inverse relationship.

Only the relationship status of couples and daily consumption showed a relationship, although the level was low (0.051). The number of family members and their dietary frequency did not have a connection to consumption in any of its forms. However, dietary habits and daily consumption did show a relationship (0.508) and dietary habits with fruit and vegetable consumption (0.210). 


\section{Discussion}

Highlighting the results of the present research of dietary habits applied to students of the different professional health-care majors, there is a low consumption of fruit, vegetables, protein-rich foods, and water; on the other hand, there is an elevated consumption of processed food and with high-calorie content. A study published by Durán et al. states that the dietary intake of nutrition students compared to other university majors has dissonant results and a lower intake of vegetables and sugary drinks but higher bread, fish, and milk intake ${ }^{9}$.

A noticeable result is that the majority of interviewed students present a BMI with normal weight; however, some were overweight, and some had a degree of obesity, and with regard to physical activity, the obtained results were discouraging, since one might think that being students in the health-care area, they should be more aware of the importance that physical activity has in their physical and emotional development. This can be compared to that published by Valdes, where the nutritional state of university students was evaluated, and both men and women were mostly normal. However, women who were enrolled in physical education majors displayed a higher value when compared to women of other majors, which could be a result of the higher level of physical activity practiced by these women ${ }^{10}$.

The previous studies conducted by Sanchez Socarrás on dietary habits in university students make the distancing from healthy dietary patterns evident: a diet is usually not enough to cover nutritional needs, especially in concert with micronutrient contribution, and students usually do not eat a proper breakfast or are used to a poor diet during examination periods ${ }^{11}$.

Likewise, the literature mentions that the prevalence of inadequate eating habits, together with the follow-up of weight loss diets aimed at satisfying the concern for their figure, together with the tendency toward a sedentary lifestyle, constitutes risk factors in the appearance of overweight and eating disorders ${ }^{11}$.

The eating habits of the university students evaluated in both men and women are on a mostly regular scale. When questioning the study population about their diet, a higher percentage sometimes answered, followed by a response of never and, discouragingly, the lowest percentage mentioned always being on a diet.

Due to these results, the eating habits that the study population follows are not important to them, since most mention not having any, likewise, the family diet, since the results reflect that the highest percentage was unhealthy, followed by not very healthy, and only a minimum percentage was considered healthy.

It can be seen in the results of Valdés that in his study, students, in general, do not exhibit major differences in the consumption of cereals and homemade food, vegetables, and fruits. However, in these past two foods, a low intake is observed concerning daily recommendations ${ }^{10}$, which would affect the nutritional status of the students. Which according to what $\mathrm{He}$ et al. found, the increase in the intake of fruits and vegetables is associated with a decrease in weight gain ${ }^{12}$, having similarities to the study by Duran, where it is pointed out that the consumption of fruits is associated with having a better BMI in students ${ }^{13}$.

According to the instrument applied to evaluate eating habits in the university population of the health sciences area, it is appreciated that the university students evaluated, both men and women, are on a mostly regular scale, and when questioning the study population about their diet, only a minimum percentage mentioned always being on a meal plan.

It is a priority to continue monitoring the eating habits of higher education students at the Juarez University of the State of Durango, which will allow the design of nutritional interventions for the prevention of diseases related to poor diet and the nutritional control of subjects as well as carry out confirmatory studies of the main findings mentioned above.

\section{Conclusions}

In this study of eating habits in the studied population, the students do not consider it important to stick to a diet since the results showed that scholars in the health sciences area of the UJED have low consumption of fruits, vegetables, water, cereals, etc. In contrast, there is a high intake of processed food with a high-caloric content. The highest percentage of the interviewed students presented a BMI with normal weight but low physical and a predominantly sedentary lifestyle.

Based on these results, it is evident that healthy eating habits should be promoted within the university population to improve their health and develop actions to prevent possible chronic degenerative non-communicable diseases in the short and/or medium term, as well as carry out campaigns to recommend physical activity, 
which will bring favorable benefits to the student population.

\section{Acknowledgments}

The authors thank the Juarez University of the State of Durango and the students from the Health Science programs for the support, time, and disposition to conduct this investigation.

\section{Conflicts of interest}

The authors declare not to have any conflicts of interest.

\section{Financing}

The authors did not receive any sponsorship for the creation of this article.

\section{Ethical disclosures}

Protection of human and animal subjects. The authors declare that no experiments were performed on humans or animals for this study.

Confidentiality of data. The authors declare that no patient data appears in this article.
Right to privacy and informed consent. The authors declare that no patient data appears in this article.

\section{References}

1. Encuesta Nacional de Salud y Nutrición. ENSANUT 2018. Available from: https://ensanut.insp.mx/encuestas/ensanut2018/doctos/informes/ensanut 2018 presentacion resultados.pdf

2. Pérez NE, Morales EM, Grajales Al. Panorama epidemiológico de la obesidad en México. Rev Mex Enf Cardiol. 2006;14:62-4.

3. Norma Oficial Mexicana NOM-174-SSA1-1998. Para el Manejo Integra de la Obesidad. Publicada en el Diario Oficial de la Federación. México: Secretaría de Salud; 2001.

4. Obesidad, Alimentación y Actividad Física. Organización Panamericana de la Salud; 2003.

5. OMS. Organización Mundial de la Salud. Recomendaciones Mundiales Sobre Actividad Física Para la Salud; 2020. Available from: https://www. who.int/es

6. Mercedes DL. Tratamiento cognitivo conductual de la obesidad. Trast Cond Aliment. 2011;14:1490-504.

7. Wing RR, Phelan S. Long-term weight loss maintenance. Am J Clin Nutr. 2005;82:222-5.

8. Izquierdo HA, Armenteros BM, Lancés CL, Martín GI. Alimentación saludable. Rev Cubana Enferm. 2004:20:1.

9. Durán AS, Valdés BP, Godoy CA, Herrera VT. Consumo de frutas y su asociación con el estado nutricional en estudiantes universitarios chilenos de la carrera de educación física. Nutr Hosp. 2015;31:2250-5.

10. Valdés BP, Godoy CA, Herrera VT, Durán AS. Comparación en hábitos alimentarios y condición física entre estudiantes de educación física y otras carreras universitarias. Nutr Hosp. 2015;32:829-36.

11. Sánchez SV, Aguilar MA. Hábitos alimentarios y conductas relacionadas con la salud en una población universitaria. Nutr Hosp. 2015;31:449-57.

12. He K, Hu FB, Colditz GA, Manson JE, Willett WC, Liu S. Changes in intake of fruits and vegetables in relation to risk of obesity and weight gain among middle-aged women. Int Jobes Relat Metab Disord. 2004:28:1569-74.

13. Durán AS, Bazaez DG, Figueroa VK, Berlanga ZM, Encina VC, Rodríguez NM. Comparación en calidad de vida y estado nutricional entre alumnos de nutrición y dietética y de otras carreras universitarias de la Universidad Santo Tomas de Chile. Nutr Hosp. 2012;27:739-46. 


\section{Annex}

Annex 1. Instrument to evaluate dietary habits in Health Sciences students

Instructions: Next, items are broken down that refers to the evaluation of a diet in Health Sciences students, so please answer all questions and mark the most appropriate answer with an $\mathrm{X}$.

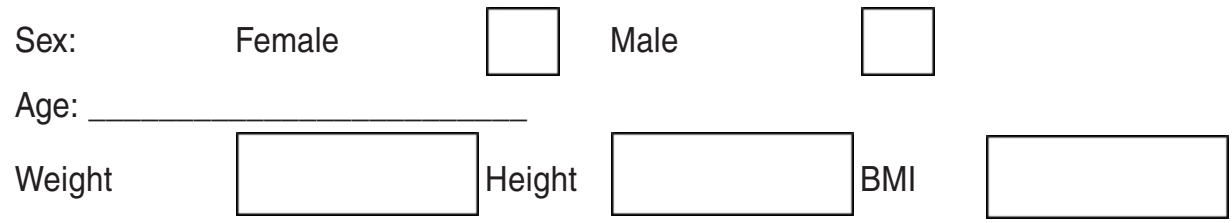

1. How do you consider your eating habits?

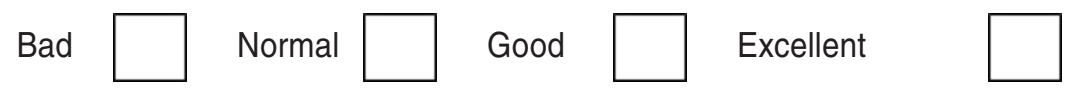

2. Do you follow a diet?
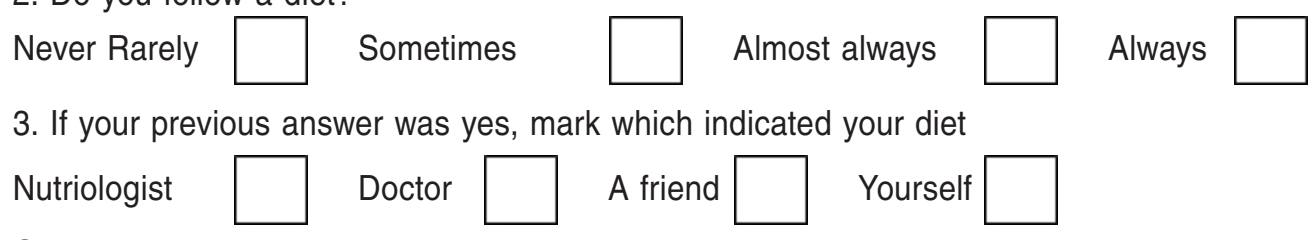

3. If your previous answer was yes, mark which indicated your diet

Other

4. Do you follow the indications that they suggested in your diet?
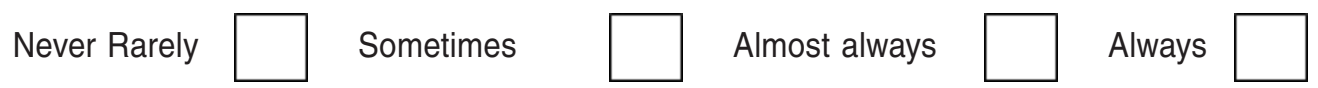

5. Do you respect customs in the eating habits of your family?

Never Almost never

Sometimes

Almost always

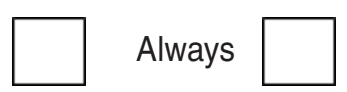

6. How often do you perform the following habits:

\begin{tabular}{|c|c|c|c|c|c|}
\hline & Never & Almost never & Sometimes & Almost always & Always \\
\hline \multicolumn{6}{|l|}{ Eat breakfast at home } \\
\hline \multicolumn{6}{|l|}{ Eat lunch at home } \\
\hline \multicolumn{6}{|l|}{ Eat dinner at home } \\
\hline \multicolumn{6}{|l|}{ Make your own meals } \\
\hline \multicolumn{6}{|c|}{ Consume snacks during the day } \\
\hline Perform physical exercise & & & & & \\
\hline
\end{tabular}

7. How often do your family members eat the following foods:

\begin{tabular}{|c|c|c|c|c|c|}
\hline & Never & Almost never & Sometimes & Almost always & Always \\
\hline \multicolumn{6}{|c|}{ Vegetables } \\
\hline \multicolumn{6}{|l|}{ Fruit } \\
\hline \multicolumn{6}{|c|}{ Legumes } \\
\hline \multicolumn{6}{|l|}{ Cereals } \\
\hline \multicolumn{6}{|l|}{ Rice } \\
\hline \multicolumn{6}{|l|}{ Milk } \\
\hline \multicolumn{6}{|l|}{ Yogurt } \\
\hline Cheese & & & & & \\
\hline
\end{tabular}


Medicina Universitaria. 2021;23(4)

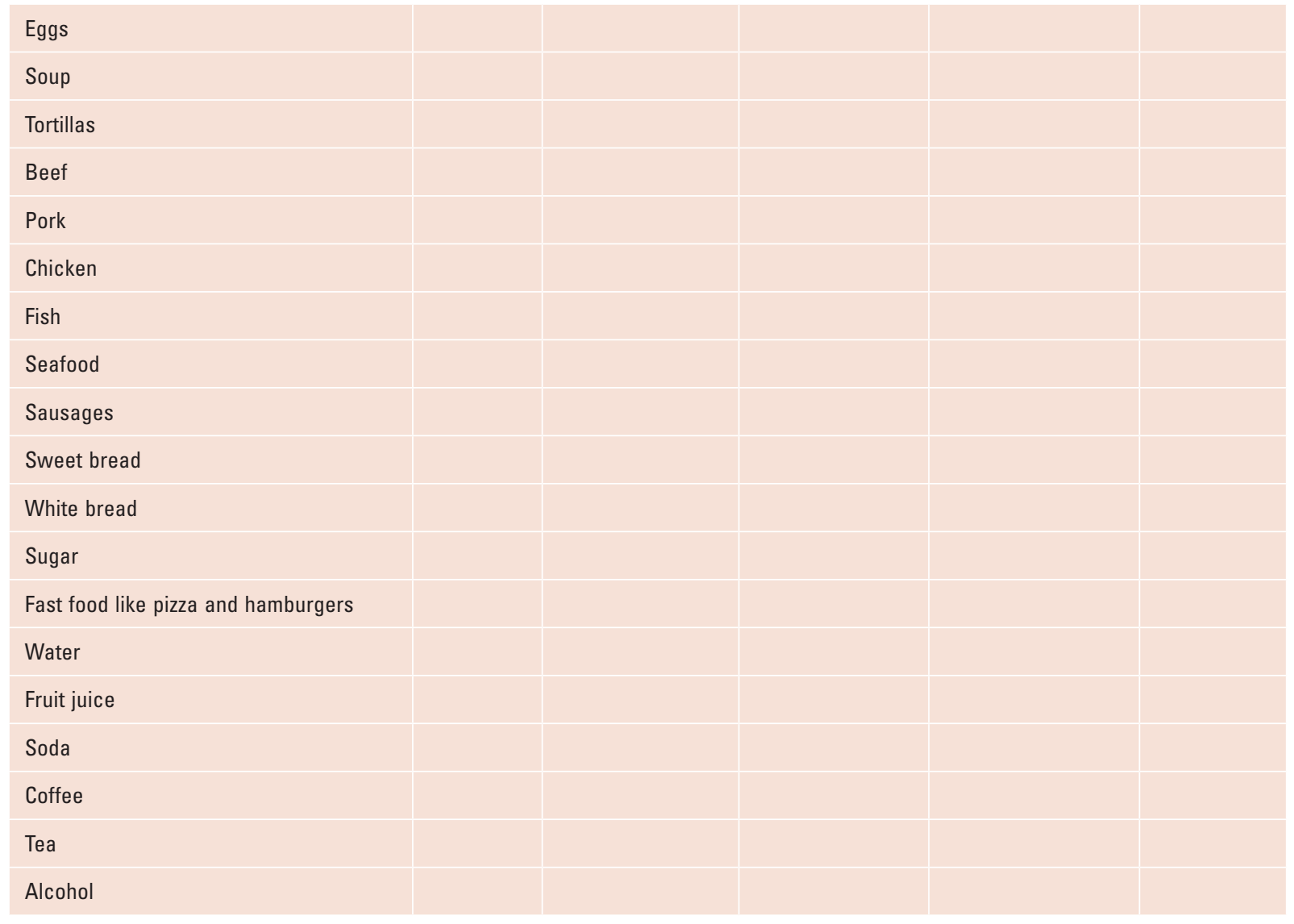

